\title{
A Study on the Relationship between Corporate Governance Ratings and Company Value: Empirical Evidence for S\&P 100 Companies
}

\author{
Ştefan Cristian Gherghina ${ }^{1}$, Georgeta Vintilă ${ }^{1} \&$ Ioana Laura Țibulcă ${ }^{1}$ \\ ${ }^{1}$ Department of Finance, Bucharest University of Economic Studies, Bucharest, Romania \\ Correspondence: Ştefan Cristian Gherghina, Bucharest University of Economic Studies, 6 Romana Square, \\ district 1, postal code 010374, Bucharest, Romania. Tel: 40-21-319-1900. E-mail: stefan.gherghina@fin.ase.ro
}

Received: April 9, 2014

Accepted: April 29, 2014

Online Published: June 25, 2014

doi:10.5539/ijef.v6n7p242

URL: http://dx.doi.org/10.5539/ijef.v6n7p242

\begin{abstract}
The goal of the current study is to examine the relationship between corporate governance ratings and company value, for all the companies included in the S\&P 100 Index, with the exception of companies involved in the financial sector, using data for 2013. The value of the company is quantified using the Tobin's Q ratio and the Enterprise Value, adjusted according to each activity sector. The corporate governance practices are reflected using the ISS Governance QuickScore 2.0 overall rating, provided by the Institutional Shareholder Services Inc. (ISS), as well as ratings for the board structure, compensation, shareholder rights, and audit. By estimating cross-section regression equations, we revealed the lack of a statistically significant relationship between the corporate governance ratings and company value. Therefore, when making investment decisions, these corporate governance ratings should be taken into consideration with certain reservations.
\end{abstract}

Keywords: agency theory, corporate governance ratings, company value, cross-section regression models

\section{Introduction}

Agency theory (Jensen \& Meckling, 1976) distinguishes between the objectives of the managers and insiders and those of the external investors. According to Core et al. (1999) companies with instable corporate governance structures deal with significant agency problems. Also, large corporations tend to separate the parties with control rights from those with residual claims (Fama, 1980; Demsetz \& Lehn, 1985). Agency theory highlights improvements regarding issues related to principal-agent objectives' congruence and information asymmetry between shareholders and managers. Through efficient corporate governance, the agency costs due to separation between ownership and control are diminished, and also, the time and resources used by investors to monitor the management are reduced (Drobetz, 2002). Moreover, there are voices which claim that the existence of superior corporate governance practices leads to an increase in company value. Firstly, adequate corporate governance boosts investors' confidence. The investors will perceive well-governed companies as being less risky, considering a low expected rate of return, which will lead to an increased value for the company. Secondly, well-governed companies will have more efficient operations, which will result in superior future cash-flows. Corporate governance is influenced by existing mechanisms at state level, as well as at company level. State level mechanisms include the legal system, the culture, the practices, and the institutions which oversee regulations conformity. Company level mechanisms which safeguard the interests of minority shareholders are expensive. The implementation of such mechanisms represents an investment for the company, and the return rate varies from state to state and from company to company (Doidge et al., 2007).

The use of corporate governance specific attributes can take the form of signals to potential investors that the company is well-governed. Such signals help the company gain access to external funds under favorable terms, leading to an increase in company value. Furthermore, the corporate governance guidelines can act as a commitment device to ensure investors that the company will adhere to superior corporate governance standards (Licht, 2003; Doidge et al., 2004). Accordingly, there are different costs associated to the implementation of solid corporate governance specific mechanisms. Transaction costs associated with reporting significant changes include the costs of association, setting the nominating committee and remuneration of the external auditors, the publishing of information to increase corporate transparency. Private costs related to the major shareholders are associated with a reduced ability of the company to extract private benefits at the expense of the minority shareholders. 
Empirical evidence on the importance of corporate governance ratings and their ability to predict future events or performance are not satisfactory. A low predictive ability cannot clarify whether shareholders and boards of directors should express their concerns regarding the company's ratings or change governance practices when this is required by governance monitors. Moreover, there are voices which claim that commercial ratings provide conclusive and infallible assessments of corporate governance. Companies that provide such ratings illustrate a significant commercial success. Also, commercial ratings use quantitative algorithms that emphasize their broad expertise on the relationship between corporate governance options and company performance. On the other hand, ratings calculated according to their own methodology consider the number of governance mechanisms based on their quality, equally weighting indicators which differ in terms of importance and ignoring the hypothesis that some of the provisions may be substituted (Larcker et al., 2007). Commercial indices evaluate each company against the industry or the size of the other companies, while academic indices are absolute measures built without regard to changes in governance practices in the studied industrial sectors. Additionally, the algorithms specific to commercial ratings change annually to take market trends into account, while academic ratings are similarly constructed for each year. While commercial ratings use large databases consisting of multiple sources, academic ratings are designed based on limited data sources such as the Investor Responsibility Research Center (IRRC), built significantly on practices adopted against takeovers (Daines et al., 2010).

The purpose of this study is to establish the relationship between commercial ratings related to corporate governance and company value for companies listed in the United States. The novelty of this study is the use of the ISS Governance QuickScore 2.0 ratings reported by the Institutional Shareholder Services Inc. (ISS). However, current research also aims to provide updated empirical evidence towards a previous study (Vintilă \& Gherghina, 2012) which used Governance Risk Indicators (GRId), provided by Institutional Shareholder Services (ISS). If governance ratings identify those characteristics that determine desirable or unexpected results, users of these measures may obtain superior risk-adjusted returns by investing in companies with strong governance or avoiding companies with poor governance related practices. The usefulness of our current research lies in the global information provided to investor by the corporate governance ratings on which investment decisions can be based. The current study is structured as follows. The second section presents the results of previous studies, developing the research hypothesis. In the third section we describe the database and research methodology, while the fourth section presents the results of the empirical research. The last section is dedicated to the conclusions of our research.

\section{Literature Review and Research Hypothesis}

Following a research based on the ISS factors, Bebchuk and Hamadani (2009) found consistency with dispersed ownership specific to U.S. companies, namely a diminished suitability for companies with concentrated ownership which seek the protection of minority shareholders against expropriation of the control group. Given that most companies that provide specific corporate governance ratings operate in the United States, we highlight a typical shareholder perspective, while in other jurisdictions, such as Continental Europe, the goal is conflict resolution and the needs of stakeholders, including investors, creditors, and employees.

Based on data provided by IRRC, Gompers et al. (2003) built a corporate governance index used for valuing the rights of shareholders in 1500 U.S. companies for the period between 1990 and 1999 based on 24 criteria. Thus, using this governance index, the authors conceived an investment strategy where the shares of companies with strong shareholder rights (Democracy Portfolio) were purchased while the shares of companies with reduced shareholder rights (Dictatorship Portfolio) were sold and they recorded abnormal returns of $8.5 \%$ per year. It was also found that companies with strong shareholder rights recorded higher values, profits and sales growth rates, lower capital costs, and made fewer corporate acquisitions. By developing an investment strategy that involved buying shares of companies characterized by high takeover vulnerability and high stakes for public pension funds, namely the sale of shares belonging to companies characterized by low takeover vulnerability and high stakes related to public pension funds, Cremers and Nair (2005) identified abnormal annual returns of $10 \%$ and $15 \%$ using the index developed by Gompers et al. (2003). Contrary, by buying shares of companies characterized by high takeover vulnerability and reduced participation of public pension funds, namely the sale of shares of companies characterized by low takeover vulnerability and reduced participation of public pension funds, no significant abnormal returns have resulted.

Brown and Caylor (2006) built the Gov-Score index based on 51 criteria, considering the data provided by the ISS for 1868 U.S. companies in 2003, identifying seven measures of corporate governance positively associated with the value of companies. With a sample of 2106 U.S. companies for the period 2002-2003 and 39 structural measures related to corporate governance, Larcker et al. (2007) used principal component analysis resulting in 
14 relevant dimensions associated with future operating performance and stock returns. Lehn et al. (2007) have identified the fact that valuation multiples for the year 1980, the period preceding the introduction of the criteria included in the indices, are strongly correlated with their values for 1990. Also, using the valuation multiples for the period 1980-1985 as a control group, the results did not reveal a significant relationship between current values of the ratio between the market value and the book value of company equity and governance indices (the GIM Index and the BCF Index) in 1990. Therefore, companies that record low values associated with valuation multiples are poorly managed and are targets of corporate control, while having limited growth opportunities. Measures shall be taken against takeovers by other companies, resulting in a decrease of indices' values. Bhagat and Bolton (2008) have identified that good corporate governance measured by indices of governance (the GIM Index and the BCF Index), share participation of board members, different persons occupying the positions of CEO of the company and Chairman of the Board of Directors, are significantly positively correlated with current and future operational performance. Using data provided by the ISS, Brown and Caylor (2009) identified six provisions related to corporate governance which were positively associated with operational performance.

By selecting a sample provided by the ISS, comprising of 2300 companies for the years between 2003-2005, Chhaochharia and Laeven (2009) showed the typical attributes of corporate governance imposed by regulations as well as attributes adopted voluntarily, stressing the fact that companies that voluntarily adopt a rigorous governance structure will register a positive effect on their company value. According to Durnev and Kim (2005), investment opportunities, external financing, and ownership structure, are associated with practices related to reporting and governance quality and companies with high ratings on governance and transparency record higher company values. Also, Doidge et al. (2007) emphasized the high explanatory capacity of the characteristics of each state (from $39 \%$ to $73 \%$ ) for the variation of governance ratings than that of the observable characteristics of companies (from $4 \%$ to $22 \%$ ).

On the other hand, replicating the index designed by Gompers et al. (2003), Core et al. (2006) concluded that shareholders' rights are not a cause of future abnormal returns, reduced shareholder rights are associated with diminished values of the rate of return on assets, but without a causal relationship. Considering data from IRRC, Bebchuk et al. (2009) constructed an index based on six criteria, resulting in a negative relation between it and corporate performance represented by the Tobin's Q ratio and stock returns for the period 1990-2003. Taking into account the clustering of industries, Johnson et al. (2009) identified the lack of significant differences between long-term returns associated to companies taking a significant number of provisions against takeovers compared to other companies. Based on the Corporate Governance Quotient index (CGQ) reported by the ISS, Epps and Cereola (2008) identified the lack of a significant relationship between the corporate governance rating and operational performance represented by the rate of return on assets and the return on equity ratio. Ertugrul and Hegde (2009) have established that the ratings developed by TCL (The Corporate Library) and the ISS are negatively associated with future operating performance, while the GMI ratings (Governance Metrics International) are positively correlated. Daines et al. (2010), using the CGQ (RiskMetrics/ISS), GMI, and TCL indices, have identified a lack of predictive skills regarding future performance.

Corporate governance rating using indicators and scores was also undertaken in other countries. Bauer et al. (2004) used the Deminor ratings for a sample of companies included in the FTSE Eurotop 300 Index, companies belonging to the member states of the Economic and Monetary Union and also from the United Kingdom, for the period from 2000 to 2001, revealing a positive link between governance ratings and company value represented by the Tobin's Q ratio. The strength of the relationship diminished after adjustments were made according to each country. The authors also uncovered a negative relationship between governance ratings and company performance represented by the net profit margin and the return on equity rate. Building a corporate governance index using data from 91 companies in Germany, Drobetz et al. (2004) identified a positive influence on the market value and stock returns associated to the rating. Using a similar investment strategy to that proposed by Gompers et al. (2003) the authors obtained an abnormal return rate of 12\%. Klapper and Love (2004) used the Credit Lyonnais Securities Asia index (CLSA) for a sample of 495 companies in 14 emerging countries and identified its association with operating performance represented by the return on assets rate and the market value of companies.

Beiner et al. (2006) have developed a corporate governance index for 275 Swiss listed companies in 2005, resulting in a positive relationship between it and the value of the companies. By developing a corporate governance index for a sample of 515 Korean companies, in 2001, Black et al. (2006a) identified the fact that improving the related scores lead to an increase in the Tobin's Q ratio of 0.47 or an increase of $160 \%$ for the stock market rates. For companies in Russia, Black et al. (2006b) established that improving the scores related to a combined index (consisting of the following indices: Brunswick UBS Warburg-Brunswick, Troika 
Dialog-Troika, S\&P Corporate Governance-S\&P Governance, S\&P Transparency and Disclosure-S\&P Disclosure, Institute of Corporate Law and Governance - ICLG, Russian Institute of Directors/Expert - RID) caused a variation in $\ln$ (Tobin's Q) of 0.45 or an increase in stock market rates of $81 \%$. For the Brunswick Index, the results showed an increase in $\ln$ (Tobin's Q) of 0.70 or a variation in stock market rates of $143 \%$. For companies listed in Hong Kong, Cheung et al. (2007) identified a positive relationship between the market value and the corporate governance index built based on the OECD Principles and the Code of Ethical Issues of the Hong Kong Stock Exchange. El Mehdi (2007) established the existence of a positive link between corporate governance and the marginal market value, for a sample of 24 Tunisian listed companies, covering the period between 2000 and 2005. For a sample of Japanese companies, Bauer et al. (2008) established that the portfolio consisting of companies with high governance ratings, based on the GMI, recorded a $15 \%$ higher return rate than the portfolio consisting of companies with low ratings, similar to Gompers et al. (2003) and Drobetz et al. (2004) Selecting a sample of 46 companies listed in Venezuela, in 2004, Garay and González (2008) built a corporate governance index identifying an average increase of $11.3 \%$ in the dividend distribution rate, a $9.9 \%$ increase for the ratio between the market value and the book value of the capital and a $2.7 \%$ increase of the Tobin's $Q$ ratio for a $1 \%$ increase in the governance index.

Using 44 corporate governance specific attributes based on data supplied by the ISS, Aggarwal et al. (2009) built a governance index whose value is influenced by the level of protection of minority shareholders. They used information for 5296 U.S. companies, respectively for 2234 companies out of 23 developed countries in 2005. The results showed a decrease in the value of non-US companies for a decreasing rating value, unlike U.S. companies. Thus, a reduced protection of investors and other characteristics of the analyzed countries highlighted the suboptimal character of investments regarding corporate governance compared to U.S. firms. According to Bruno and Claessens (2010), the company value is influenced by the level of protection of the shareholders and by corporate governance practices at the company level. Bauwhede (2009) identified a positive relationship between compliance with international good-practices regarding the board structure and operational performance represented by the rate of return on assets. Bozec et al. (2010), using a sample of 130 Canadian companies for the period during 2002-2005, identified a positive relationship between the corporate governance index ROB (reported by The Globe and Mail) and the Tobin's Q ratio when there is a separation between voting rights and cash-flow rights. Using Deminor ratings for 1199 companies included in the FTSEurofirst 300 Index, from 14 European countries, over the period between 1999 and 2003, Renders et al. (2010) identified a positive relationship between governance ratings and company performance. Moreover, in countries with strong protection of shareholders, the companies recorded high corporate governance ratings, but the impact of corporate governance on company performance was reduced compared to countries with a low protection of shareholders where improving corporate governance is a cost signal which leads to reduced private benefits. For companies in Thailand during 2001-2006, Hodgson et al. (2011) have established that firms with good corporate governance practices, reflected by the governance index reported by the Thai Institute of Directors (IOD), recorded higher values and performance.

Compared with previous studies, current research employs ISS Governance QuickScore 2.0 ratings reported by the Institutional Shareholder Services Inc. (ISS), the largest and most influential proxy advisory firm, as measures for corporate governance, never used before, thus providing the first empirical results. Therefore, the current updated rating system depicts the fifth iteration of ISS's corporate governance rating system, following the Corporate Governance Quotient (CGQ), the Governance Risk Indicators database (GRId 1.0 and GRId 2.0), as well the original QuickScore. Hence, in contrast to previous ISS corporate governance ratings, QuickScore 2.0, launched on February 18, 2014, shows a methodology expansion for its data-driven, governance risk scoring system, and analytical tool. In addition, it covers the following updates: event-driven data updates (ongoing updates as regards the firm profile and score based on changes occurred within the firm governance structure ascertained from publicly available information), new and updated governance factors related to board diversity and refreshment, and director compensation, zero-weight factors (informational-only factors without any influence on firm score), modified scoring (the release of a modified scoring methodology in order to optimize alignment with ISS voting policy, global governance standards, and best practices), and expanded coverage for corporations in the U.K. and Australia.

Based on these findings, we will consider the following research hypothesis: Taking the agency theory into account, we expect to reveal a positive relationship between the corporate governance ratings and company value. 


\section{Database Description and Research Methodology}

\subsection{Database and Variables' Description}

Initially, the research sample consisted of all the U.S. companies included in the S\&P 100 Index in the year 2013. The S\&P 100 index is a subset of the S\&P 500 and comprises 100 major, blue chip companies across multiple industry groups, weighted for market capitalization, being traded on the Chicago Board Options Exchange (CBOE). Constituents of the S\&P 100 emphasize about 57\% of the market capitalization of the S\&P 500 and almost $45 \%$ of the market capitalization of the United States equity markets. We have selected the companies out of S\&P 100 Index since this index is used as a benchmark to measure the performance of large cap stocks. Furthermore, we underline two broad categories as regards the users of S\&P 100 Index options: institutional asset managers and traders, as well individual investors. Likewise, the individual investors who use S\&P 100 options range from conservative blue-chip investors to more aggressive stock market traders.

Subsequently, we eliminated the companies that operated in the financial sector (17 companies), resulting a final sample consisting of 83 companies. The companies included in the research database operate in a variety of business sectors: basic materials sector (14), consumer goods (11), healthcare sector (12), industrial goods sector (10), services (19), technology (14), and utilities (3).

In Table 1 we have listed the variable we used in the empirical research. To render the company value we considered the Tobin's Q ratio according to Kaplan and Zingales (1997), Gompers et al. (2003), and Bebchuk et al. (2009). After calculating the Tobin's Q ratio for each company, we proceeded to adjust the results based on the activity sector, similar to Eisenberg et al. (1998), due to the great diversity of activity sectors in which the companies included in the research database operate. The difference between the Tobin's Q ratio for each company and the median ratio for the respective sector represents the $\Delta \mathrm{Q}$, and the adjusted ratio, QAdj, is defined as: $\mathrm{QAdj}=\operatorname{sign}(\Delta \mathrm{Q}) * \operatorname{sqrt}(|\Delta \mathrm{Q}|)$, where $\operatorname{sign}(\Delta \mathrm{Q})$ represents the sign of the difference between the Tobin's $Q$ ratio for each company and the median ratio for the respective activity sector. The median was preferred to the mean because the data did not follow a normal distribution. The source for the financial information is represented by the annual financial reports of each company. Additionally, in order to quantify the company value we used the Enterprise Value indicator, which was adjusted according to the sector in which the company operates, similarly to the Tobin's Q ratio.

In order to valuate corporate governance practices, data was collected regarding ISS Governance QuickScore 2.0 ratings provided by the ISS. The ISS Governance QuickScore 2.0 represents a valuation and monitoring instrument designed for institutional investors in order to better indentify the risk related to a certain company in a portfolio.

Table 1. Description of variables used in the empirical research

\begin{tabular}{|c|c|}
\hline Variables & Definition \\
\hline \multicolumn{2}{|c|}{ Variables for the company value } \\
\hline QAdj & $\begin{array}{l}\text { The Tobin's Q ratio, adjusted according to the activity sector, calculated as the ratio between the market value of the } \\
\text { assets (book value of assets - book value of equity + market value of equity) and the book value of the assets. }\end{array}$ \\
\hline EVAdj & $\begin{array}{l}\text { The value of a company if it was the object of an acquisition (Enterprise Value), adjusted according to the activity sector, } \\
\text { calculated as market capitalization + total liabilities - available cash and short-term investments }\end{array}$ \\
\hline \multicolumn{2}{|c|}{ Variables regarding corporate governance } \\
\hline QuickScore & $\begin{array}{l}\text { The overall corporate governance indicator ISS Governance QuickScore 2.0, as provided by the Institutional Shareholder } \\
\text { Services Inc. (ISS). }\end{array}$ \\
\hline BoardStructure & The Board Structure Indicator as provided by the Institutional Shareholder Services Inc. (ISS). \\
\hline Compensation & The Compensation Indicator as provided by the Institutional Shareholder Services Inc. (ISS). \\
\hline ShRights & The Shareholders Rights Indicator as provided by the Institutional Shareholder Services Inc. (ISS). \\
\hline Audit & The Audit Practices Indicator as provided by Institutional Shareholder Services Inc. (ISS). \\
\hline \multicolumn{2}{|c|}{ Control variables } \\
\hline Size & Number of full-time employees for each company (log values). \\
\hline Leverage & Leverage, calculated as the ratio between total debt and total assets. \\
\hline GR & Annual turnover growth rate for the previous 5 years (\%). \\
\hline Listing & Number of years since the company was listed on the New York Stock Exchange or on NASDAQ (log values). \\
\hline
\end{tabular}

Source: Authors' processing. 
There are indices reported for 4100 companies in 25 countries, including companies in the U.S. Russell 3000 Index and the Canadian S\&P/TSX Composite Index, companies from the UK, Europe, Japan, and Asia Pacific included in the MSCI-EAFE Index, as well as companies from the UK and Australia included in UK Euro Stoxx Index and the Australia ASX 200 Index. QuickScore 2.0 evaluates approximately 200 corporate governance specific factors in the following categories representing different ratings, but also subsequently resulting in an overall rating: board structure (board composition and committees, board practices and policies, related party transactions), shareholder rights (one share-one vote, takeover defenses, issues and formalities regarding voting, and other shareholder rights issues), compensation (pay based on performance, non-performance based pay, use of equity, equity risk mitigation, remuneration of non-executive administrators, termination, controversies), audit (external auditor, audit and accounting controversies, other issues regarding audit). QuickScore 2.0 reports a numerical score based on deciles, indicating the corporate governance risk to the index or industry. A score of 1 indicates a relatively low governance risk, while scoring 10 reveals a relatively high governance risk.

We will also include a set of control variables. As large companies face severe agency problems and can voluntarily select specific strict corporate governance rules (Jensen, 1986), we will include a control variable for company size, measured by the number of full-time employees within each company (logarithmic values). We will use the ratio between total debt and total assets as a control variable for indebtedness. Jensen $(1986,1993)$, Stulz (1990), and Hart and Moore (1995) suggested that borrowing funds deters managers from overinvesting the net cash-flow. Moreover, leverage can create added value giving company management the opportunity to highlight the ability to distribute cash-flow and to be monitored by creditors. Also, mature companies having stable cash-flows, will tend to be more indebted in order to discipline the managers (Jensen, 1986). According to Zweibel (1996), a high leverage level reduces the likelihood of takeovers by other companies, which means that levered companies are less vulnerable to takeovers. To measure the growth opportunities of a company we will use the compound annual growth rate of the turnover for the previous five years. Companies that register growth opportunities will require increased external financing and may deem best an improvement in governance standards to reduce the cost of capital. Klapper and Love (2004) and Durnev and Kim (2005) noted that companies that register investment opportunities and external financing requests, have incentives for the implementation of superior governance practices. Furthermore, we will also include a control variable for the number of years that the company has been listed on the New York Stock Exchange or the NASDAQ electronic exchange (logarithmic values).

\subsection{Research Methodology}

In order to highlight the relationship between corporate governance ratings and company value, we will estimate multiple linear regression models, using the following general pattern (Gujarati, 2003):

$$
\text { Firm_value }_{i}=\beta_{0}+\beta_{1} X_{i}+\beta_{2} Z_{i}+u_{i} \quad i=1, \ldots, N
$$

where, for company i, we consider as independent variables the Tobin's Q ratio and the Enterprise Value, both adjusted according to the activity sector, and as independent variables, $X_{i}$, the corporate governance overall rating and the ratings for board structure, shareholder rights, compensation, and audit, while $Z_{i t}$ is the vector of control variables.

\section{Research Results}

\subsection{Descriptive Statistics}

Table 2 presents the descriptive statistic results for the variables we used in our empirical research.

Table 2. Descriptive statistics for the variables used in the empirical research

\begin{tabular}{lcccccc}
\hline Variables & $\mathrm{N}$ & Mean & Median & Min & Max & Std. Dev. \\
\hline \multicolumn{2}{l}{ Variables for the company value } & & & & & \\
\hline QAdj & 83 & 0.028660 & 0.000000 & -0.563058 & 0.721459 & 0.341841 \\
EVAdj & 83 & -0.001118 & 0.000000 & -1.024350 & 1.435896 & 0.695055 \\
\hline \multicolumn{2}{l}{ Variables regarding corporate governance } & & & & \\
\hline QuickScore & 83 & 4.614458 & 4.000000 & 1.000000 & 10.00000 & 3.003377 \\
BoardStructure & 83 & 5.313253 & 5.000000 & 1.000000 & 10.00000 & 2.780278 \\
Compensation & 83 & 5.216867 & 5.000000 & 1.000000 & 10.00000 & 2.967500 \\
ShRights & 83 & 4.253012 & 4.000000 & 1.000000 & 10.00000 & 2.814784 \\
Audit & 83 & 1.542169 & 1.000000 & 1.000000 & 10.00000 & 2.154412 \\
\hline
\end{tabular}




\begin{tabular}{lllllll}
\hline Control variables & \multicolumn{7}{l}{} \\
\hline Size & 83 & 11.21955 & 11.29352 & 8.583355 & 14.50866 & 1.136970 \\
Leverage & 83 & 0.584815 & 0.575038 & 0.135513 & 1.203469 & 0.171633 \\
GR & 83 & 0.474184 & 0.272000 & -0.618900 & 9.131300 & 1.075185 \\
Listing & 83 & 3.545437 & 3.784190 & 0.000000 & 4.795791 & 0.972810 \\
\hline
\end{tabular}

Source: Authors' computations. The description of the variables is provided in Table 1.

Table 3 shows the frequency of companies considering the level of corporate governance risk. Looking at the average values corresponding to the auditing practices index provided by the Institutional Shareholder Services Inc. (ISS) we can conclude that companies in the sample recorded a relatively low governance risk. Furthermore, we highlight the fact that $93.97 \%$ of the companies in the research sample recorded a relatively low governance risk, if we analyze the audit rating values. While looking at the average values for the overall corporate governance rating and the corresponding values for the ratings regarding board structure, compensation, and shareholder rights, we find a relative medium risk, highlighted by average values between four and five.

Table 3. Companies' frequency considering the level of corporate governance risk

\begin{tabular}{lcccc}
\hline Variables & $\begin{array}{c}\text { Number of companies with a } \\
\text { relatively low governance risk (1) }\end{array}$ & $\%$ & $\begin{array}{c}\text { Number of companies with a relatively } \\
\text { high governance risk (10) }\end{array}$ & $\%$ \\
\hline QuickScore & 14 & 16.8675 & 8 & 9.6386 \\
BoardStructure & 7 & 8.4337 & 7 & 8.4337 \\
Compensation & 11 & 13.2530 & 10 & 12.0482 \\
ShRights & 15 & 18.0723 & 6 & 7.2289 \\
Audit & 78 & 93.9759 & 5 & 6.0241 \\
\hline
\end{tabular}

Source: Authors' computations. The description of the variables is provided in Table 1.

Table 4 presents the Pearson correlation coefficients' matrix.

Table 4. The correlation coefficients' matrix

\begin{tabular}{|c|c|c|c|c|c|c|c|c|c|c|c|}
\hline & 1 & 2 & 3 & 4 & 5 & 6 & 7 & 8 & 9 & 10 & 11 \\
\hline 1 QAdj & 1 & $\begin{array}{l}-.001 \\
(.993)\end{array}$ & $\begin{array}{l}-.082 \\
(.458)\end{array}$ & $\begin{array}{c}.035 \\
(.752)\end{array}$ & $\begin{array}{l}-.036 \\
(.749)\end{array}$ & $\begin{array}{l}-.054 \\
(.626)\end{array}$ & $\begin{array}{l}-.011 \\
(.919)\end{array}$ & $\begin{array}{c}.202 \\
(.066)\end{array}$ & $\begin{array}{c}\mathbf{. 8 5 1}^{* *} \\
(0)\end{array}$ & $\begin{array}{l}-.274^{*} \\
(.012)\end{array}$ & $\begin{array}{l}-.026 \\
(.813)\end{array}$ \\
\hline 2 EVAdj & $\begin{array}{l}-.001 \\
(.993)\end{array}$ & 1 & $\begin{array}{l}-.128 \\
(.249)\end{array}$ & $\begin{array}{l}-.046 \\
(.676)\end{array}$ & $\begin{array}{l}-.014 \\
(.901)\end{array}$ & $\begin{array}{l}-.148 \\
(.181)\end{array}$ & $\begin{array}{c}.042 \\
(.708)\end{array}$ & $\begin{array}{c}.198 \\
(.072)\end{array}$ & $\begin{array}{l}-.005 \\
(.966)\end{array}$ & $\begin{array}{c}.149 \\
(.178)\end{array}$ & $\begin{array}{c}.187 \\
(.091)\end{array}$ \\
\hline 3 QuickScore & $\begin{array}{l}-.082 \\
(.458)\end{array}$ & $\begin{array}{l}-.128 \\
(.249)\end{array}$ & 1 & $\begin{array}{c}.571^{\text {*** }} \\
(0)\end{array}$ & $\begin{array}{c}.766^{* * *} \\
(0)\end{array}$ & $\begin{array}{c}.648^{* * *} \\
(0)\end{array}$ & $\begin{array}{c}.084 \\
(.452)\end{array}$ & $\begin{array}{l}-.198 \\
(.073)\end{array}$ & $\begin{array}{l}-.144 \\
(.194)\end{array}$ & $\begin{array}{c}.202 \\
(.068)\end{array}$ & $\begin{array}{l}-.2 \\
(.07)\end{array}$ \\
\hline 4 BoardStructure & $\begin{array}{c}.035 \\
(.752)\end{array}$ & $\begin{array}{l}-.046 \\
(.676)\end{array}$ & $\begin{array}{c}. \mathbf{5 7 1}^{* *} \\
(0)\end{array}$ & 1 & $\begin{array}{c}.^{\mathbf{4 5 9}^{* * *}} \\
(0)\end{array}$ & $\begin{array}{c}.124 \\
(.265)\end{array}$ & $\begin{array}{c}-.01 \\
(.926)\end{array}$ & $\begin{array}{c}.082 \\
(.464)\end{array}$ & $\begin{array}{c}.02 \\
(.854)\end{array}$ & $\begin{array}{c}.141 \\
(.204)\end{array}$ & $\begin{array}{l}-.169 \\
(.127)\end{array}$ \\
\hline 5 Compensation & $\begin{array}{l}-.036 \\
(.749)\end{array}$ & $\begin{array}{l}-.014 \\
(.901)\end{array}$ & $\begin{array}{c}.766^{* *} \\
(0)\end{array}$ & $\begin{array}{c}. \mathbf{4 5 9}^{* * *} \\
(0)\end{array}$ & 1 & $\begin{array}{c}.17 \\
(.124)\end{array}$ & $\begin{array}{l}-.156 \\
(.159)\end{array}$ & $\begin{array}{c}-.194 \\
(.08)\end{array}$ & $\begin{array}{l}-.073 \\
(.512)\end{array}$ & $\begin{array}{c}. \mathbf{2 2 5} \\
(.041)\end{array}$ & $\begin{array}{l}-.062 \\
(.576)\end{array}$ \\
\hline 6 ShRights & $\begin{array}{l}-.054 \\
(.626)\end{array}$ & $\begin{array}{l}-.148 \\
(.181)\end{array}$ & $\begin{array}{c}. \mathbf{6 4 8}^{* * *} \\
(0)\end{array}$ & $\begin{array}{c}.124 \\
(.265)\end{array}$ & $\begin{array}{c}.17 \\
(.124)\end{array}$ & 1 & $\begin{array}{l}. \mathbf{2 3 0}^{*} \\
(.036)\end{array}$ & $\begin{array}{l}-.179 \\
(.106)\end{array}$ & $\begin{array}{l}-.093 \\
(.402)\end{array}$ & $\begin{array}{l}.149 \\
(.18)\end{array}$ & $\begin{array}{c}-. .340^{* * *} \\
(.002)\end{array}$ \\
\hline 7 Audit & $\begin{array}{l}-.011 \\
(.919)\end{array}$ & $\begin{array}{c}.042 \\
(.708)\end{array}$ & $\begin{array}{c}.084 \\
(.452)\end{array}$ & $\begin{array}{c}-.01 \\
(.926)\end{array}$ & $\begin{array}{l}-.156 \\
(.159)\end{array}$ & $\begin{array}{c}. \mathbf{2 3 0}^{*} \\
(.036)\end{array}$ & 1 & $\begin{array}{c}.087 \\
(.433)\end{array}$ & $\begin{array}{l}-.011 \\
(.923)\end{array}$ & $\begin{array}{l}-.11 \\
(.32)\end{array}$ & $\begin{array}{c}.067 \\
(.547)\end{array}$ \\
\hline 8 Size & $\begin{array}{c}.202 \\
(.066)\end{array}$ & $\begin{array}{c}.198 \\
(.072)\end{array}$ & $\begin{array}{l}-.198 \\
(.073)\end{array}$ & $\begin{array}{c}.082 \\
(.464)\end{array}$ & $\begin{array}{l}-.194 \\
(.08)\end{array}$ & $\begin{array}{l}-.179 \\
(.106)\end{array}$ & $\begin{array}{c}.087 \\
(.433)\end{array}$ & 1 & $\begin{array}{l}.256^{*} \\
(.019)\end{array}$ & $\begin{array}{l}-.259^{*} \\
(.018)\end{array}$ & $\begin{array}{c}.21 \\
(.056)\end{array}$ \\
\hline 9 Leverage & $\begin{array}{c}.851^{* * *} \\
(0)\end{array}$ & $\begin{array}{l}-.005 \\
(.966)\end{array}$ & $\begin{array}{l}-.144 \\
(.194)\end{array}$ & $\begin{array}{c}.02 \\
(.854)\end{array}$ & $\begin{array}{l}-.073 \\
(.512)\end{array}$ & $\begin{array}{l}-.093 \\
(.402)\end{array}$ & $\begin{array}{l}-.011 \\
(.923)\end{array}$ & $\begin{array}{l}.256^{*} \\
(.019)\end{array}$ & 1 & $\begin{array}{c}-.388^{* *} \\
(0)\end{array}$ & $\begin{array}{c}.094 \\
(.397)\end{array}$ \\
\hline $10 \mathrm{GR}$ & $\begin{array}{l}-.274^{*} \\
(.012)\end{array}$ & $\begin{array}{c}.149 \\
(.178)\end{array}$ & $\begin{array}{c}.202 \\
(.068)\end{array}$ & $\begin{array}{l}.141 \\
(.204)\end{array}$ & $\begin{array}{l}.225^{*} \\
(.041)\end{array}$ & $\begin{array}{l}.149 \\
(.18)\end{array}$ & $\begin{array}{l}-.11 \\
(.32)\end{array}$ & $\begin{array}{l}-.259^{*} \\
(.018)\end{array}$ & $\begin{array}{c}-. \mathbf{3 8 8}^{* * *} \\
(0)\end{array}$ & 1 & $\begin{array}{c}-.457^{* * *} \\
(0)\end{array}$ \\
\hline 11 Listing & $\begin{array}{l}-.026 \\
(.813)\end{array}$ & $\begin{array}{c}.187 \\
(.091)\end{array}$ & $\begin{array}{c}-.2 \\
(.07)\end{array}$ & $\begin{array}{l}-.169 \\
(.127)\end{array}$ & $\begin{array}{l}-.062 \\
(.576)\end{array}$ & $\begin{array}{l}-.340^{* * *} \\
(.002)\end{array}$ & $\begin{array}{c}.067 \\
(.547)\end{array}$ & $\begin{array}{c}.21 \\
(.056)\end{array}$ & $\begin{array}{c}.094 \\
(.397)\end{array}$ & $\begin{array}{c}-.457^{* *} \\
(0)\end{array}$ & 1 \\
\hline
\end{tabular}

**Significant at $1 \%$ level. *Significant at $5 \%$ level.

The description of the variables is provided in Table 1. Source: Authors' computations. 
Thus, we underline the absence of significant correlations between the variables regarding company value and the corporate governance ratings. We also note a strong correlation between the overall corporate governance index and the compensation index (0.766).

\subsection{Regression Model Results}

Table 5 presents the estimation results regarding the influence of the ratings provided by the Institutional Shareholder Services Inc. (ISS) on the adjusted Tobin's Q ratio according to the activity sector.

We point out the absence of a statistically significant relationship between the overall corporate governance rating and the value of companies included in the S\&P 100 (model 1). Moreover, no statistically significant relationship was identified between the four ratings provided by ISS and the Tobin's Q ratio adjusted according to the activity sector (models 2-5). Considering the influence of the ratings regarding the board structure, compensation, shareholder rights, and audit practices considered as independent variables in the same econometric model (model 6), the relationship was not statistically validated. In terms of the influence of the control variables, we found a positive relationship between leverage and the company value (models 1-6). Consequently, our results support the importance of the leverage level in limiting the self-serving managerial decisions regarding the use of the cash-flow (Myers, 1977).

Table 6 showcases the estimation results regarding the influence of the ratings provided by the Institutional Shareholder Services Inc. (ISS) on the adjusted Enterprise Value according to the activity sector.

The lack of a statistically significant link between the overall corporate governance rating (Model 1), the four distinct ratings (models 2-5), and the company value is confirmed. Furthermore, including the ratings regarding the board structure, compensation, shareholder rights, and audit practices as independent variables in the same econometric model (model 6), their influence on the value of the company was not statistically validated. In terms of control variables, we found a positive influence of the company size, the growth opportunities and the company's listing age (the number of years since the company has been publicly listed) on the adjusted Enterprise Value according to the activity sector.

Table 5. Results of estimations regarding the influence of the ratings provided by the Institutional Shareholder Services Inc. (ISS) on the adjusted Tobin's Q ratio according to the activity sector

\begin{tabular}{|c|c|c|c|c|c|c|}
\hline & 1 & 2 & 3 & 4 & 5 & 6 \\
\hline \multirow[t]{2}{*}{ Intercept } & $-0.903868^{* * * *}$ & $-0.877554^{\text {**** }}$ & $-0.897667^{\text {***k}}$ & $-0.863520^{* * *}$ & $-0.878965^{k * *}$ & $-0.880317^{* * *}$ \\
\hline & $(-3.847071)$ & $(-3.912315)$ & $(-3.889627)$ & $(-3.604528)$ & $(-3.930981)$ & $(-3.537054)$ \\
\hline \multirow[t]{2}{*}{ QuickScore } & 0.002425 & & & & & \\
\hline & $(0.349842)$ & & & & & \\
\hline \multirow[t]{2}{*}{ BoardStructure } & & -0.000332 & & & & -0.002074 \\
\hline & & $(-0.044892)$ & & & & $(-0.240681)$ \\
\hline \multirow[t]{2}{*}{ Compensation } & & & 0.002333 & & & 0.003831 \\
\hline & & & $(0.332708)$ & & & $(0.458076)$ \\
\hline \multirow[t]{2}{*}{ ShRights } & & & & -0.001314 & & -0.002298 \\
\hline & & & & $(-0.172343)$ & & $(-0.278728)$ \\
\hline \multirow[t]{2}{*}{ Audit } & & & & & 0.000995 & 0.002433 \\
\hline & & & & & $(0.105992)$ & $(0.240096)$ \\
\hline \multirow[t]{2}{*}{ Size } & 0.002821 & 0.002079 & 0.002954 & 0.001621 & 0.001830 & 0.003296 \\
\hline & $(0.150063)$ & $(0.110519)$ & $(0.156528)$ & $(0.086372)$ & $(0.097831)$ & $(0.166017)$ \\
\hline \multirow[t]{2}{*}{ Leverage } & $1.727227^{* * *}$ & $1.724713^{* * * *}$ & $1.722269^{* * * *}$ & $1.723251^{* * *}$ & $1.725397^{* * *}$ & $1.722821^{* * *}$ \\
\hline & $(13.32870)$ & (13.30961) & $(13.29765)$ & $(13.29625)$ & $(13.29796)$ & (13.00890) \\
\hline \multirow[t]{2}{*}{ GR } & 0.004978 & 0.005654 & 0.004004 & 0.005353 & 0.005779 & 0.003960 \\
\hline & $(0.217568)$ & $(0.246072)$ & $(0.171930)$ & $(0.234114)$ & $(0.251818)$ & $(0.166098)$ \\
\hline \multirow[t]{2}{*}{ Listing } & -0.034631 & -0.035725 & -0.036130 & -0.036874 & -0.035599 & -0.039586 \\
\hline & $(-1.468671)$ & $(-1.511849)$ & $(-1.538892)$ & $(-1.499568)$ & $(-1.518934)$ & $(-1.537580)$ \\
\hline $\mathrm{N}$ & 83 & 83 & 83 & 83 & 83 & 83 \\
\hline F-statistic & $43.07165^{* * *}$ & 42.98039 **** & $43.06278^{* * * *}$ & $43.00138^{* * *}$ & $42.98738^{* * * *}$ & $25.94022^{* * *}$ \\
\hline Adj R-sq & 0.719522 & 0.719084 & 0.719480 & 0.719185 & 0.719117 & 0.708726 \\
\hline
\end{tabular}


Table 6. Results of estimations regarding the influence of the ratings provided by the Institutional Shareholder Services Inc. (ISS) on the adjusted Enterprise Value according to the activity sector

\begin{tabular}{|c|c|c|c|c|c|c|}
\hline & 1 & 2 & 3 & 4 & 5 & 6 \\
\hline Intercept & $\begin{array}{l}-2.241689^{*} \\
(-2.630836)\end{array}$ & $\begin{array}{l}-2.437605^{* *} \\
(-2.991023)\end{array}$ & $\begin{array}{l}-2.414770^{* *} \\
(-2.871931)\end{array}$ & $\begin{array}{l}-2.300985^{*} \\
(-2.641637)\end{array}$ & $\begin{array}{l}-2.489007 * * \\
(-3.058861)\end{array}$ & $\begin{array}{l}-2.265332 * \\
(-2.511189)\end{array}$ \\
\hline QuickScore & $\begin{array}{l}-0.022741 \\
(-0.904459)\end{array}$ & & & & & \\
\hline BoardStructure & & $\begin{array}{l}-0.017257 \\
(-0.641919)\end{array}$ & & & & $\begin{array}{l}-0.018131 \\
(-0.580380)\end{array}$ \\
\hline Compensation & & & $\begin{array}{l}-0.007968 \\
(-0.311935)\end{array}$ & & & $\begin{array}{l}0.005185 \\
(0.171055)\end{array}$ \\
\hline ShRights & & & & $\begin{array}{l}-0.015884 \\
(-0.572965)\end{array}$ & & $\begin{array}{l}-0.019969 \\
(-0.668362)\end{array}$ \\
\hline Audit & & & & & $\begin{array}{l}0.014284 \\
(0.418253)\end{array}$ & $\begin{array}{l}0.022036 \\
(0.600082)\end{array}$ \\
\hline Size & $\begin{array}{l}0.123581 \dagger \\
(1.812739)\end{array}$ & $\begin{array}{l}0.137119^{*} \\
(2.006622)\end{array}$ & $\begin{array}{l}0.128189 \dagger \\
(1.864141)\end{array}$ & $\begin{array}{l}0.127307 \dagger \\
(1.866153)\end{array}$ & $\begin{array}{l}0.129512 \dagger \\
(1.902972)\end{array}$ & $\begin{array}{l}0.131116 \dagger \\
(1.822221)\end{array}$ \\
\hline Leverage & $\begin{array}{l}0.188033 \\
(0.400096)\end{array}$ & $\begin{array}{l}0.228230 \\
(0.484749)\end{array}$ & $\begin{array}{l}0.221568 \\
(0.469555)\end{array}$ & $\begin{array}{l}0.199754 \\
(0.423895)\end{array}$ & $\begin{array}{l}0.227866 \\
(0.482592)\end{array}$ & $\begin{array}{l}0.227183 \\
(0.473283)\end{array}$ \\
\hline GR & $\begin{array}{l}0.240520 * * \\
(2.898361)\end{array}$ & $\begin{array}{l}0.241020^{* *} \\
(2.887019)\end{array}$ & $\begin{array}{l}0.240484 * * \\
(2.834115)\end{array}$ & $\begin{array}{l}0.232938 * * \\
(2.801876)\end{array}$ & $\begin{array}{l}0.238629 * * \\
(2.857178)\end{array}$ & $\begin{array}{l}0.240256^{* *} \\
(2.780608)\end{array}$ \\
\hline Listing & $\begin{array}{l}0.207300^{*} \\
(2.424088)\end{array}$ & $\begin{array}{l}0.209286^{*} \\
(2.437650)\end{array}$ & $\begin{array}{l}0.218136^{*} \\
(2.550184)\end{array}$ & $\begin{array}{l}0.200771 * \\
(2.245580)\end{array}$ & $\begin{array}{l}0.216160^{*} \\
(2.534399)\end{array}$ & $\begin{array}{l}0.188016^{*} \\
(2.014793)\end{array}$ \\
\hline $\mathrm{N}$ & 83 & 83 & 83 & 83 & 83 & 83 \\
\hline F-statistic & $2.979037 *$ & $2.883152 *$ & $2.808813 *$ & $2.863367^{*}$ & $2.827148^{*}$ & $1.823973 \dagger$ \\
\hline Adj R-sq & 0.107679 & 0.102999 & 0.099337 & 0.102028 & 0.100243 & 0.074406 \\
\hline
\end{tabular}

$\dagger \mathrm{p}<0.10{ }^{*} \mathrm{p}<0.05 .{ }^{* *} \mathrm{p}<0.01 .{ }^{* * *} \mathrm{p}<0.001$. The t-statistic for each coefficient is reported in parentheses.

The description of the variables is provided in Table 1. Source: Authors' computations.

Therefore, the hypothesis regarding the existence of a positive relationship between the corporate governance ratings and the company value is rejected. According to Daines et al. (2010), corporate governance could be an endogenous choice by the corporations which optimally adjust the costs and benefits of these governance choices. Therewith, the commercial ratings contain a large amount of measurement error which alleviates the estimated coefficients in simple regressions and causes mixed estimation results depending on the covariance structure of the variables included in multivariate regressions. Therefore, the boards of directors should not enforce amendments solely for the purpose of increasing their ranking.

\section{Concluding Remarks}

By selecting a research sample consisting of all the companies included in the S\&P 100 Index and excluding the companies belonging to the financial sector, for the year 2013, we highlighted the lack of statistically significant relationship between the overall corporate governance rating ISS Governance QuickScore 2.0, provided by Institutional Shareholder Services Inc. (ISS), and the company value, represented by the Tobin's Q ratio and the Enterprise Value, both adjusted according to the activity sector. Furthermore, the absence of a statistically significant link was also confirmed for the corresponding ratings regarding the board structure, compensation, shareholder rights, and audit practices. Similar to Daines et al. (2010), commercial ratings related to governance contain numerous errors of measurement. Also, another argument may be the lack of a suitable means of estimation or appropriate measures for the company value. The companies that provide ratings may object, stating that by using suitable specifications, the ratings are meaningful and informative.

If the corporate governance ratings reveal those corporate governance characteristics that drive towards desirable or undesirable outcomes, users of these ratings may be able to earn superior risk adjusted returns by either investing in companies with good governance or avoiding companies with poor governance. Based on the explicit claims stated by the governance advisory firms such as ISS, we acknowledge the fact that investors could uncover the worst corporate offenders or could avoid huge losses during corporate scandals like Enron, Global Crossing, or WorldCom. However, by considering our empirical findings, we recommend that investors should take decisions based on the values of corporate governance ratings only with due reservations. However, 
the companies should be concerned by the level of investor protection through an enhanced disclosure, by selecting well-functioning and independent boards, by enforcing disciplinary mechanisms in order to prevent management and controlling shareholders as regards engaging in expropriation of minority shareholders. Withal, weak shareholder rights restrict the power of shareholders to hold boards to account, whereas fairness and transparency within financial markets imply investor confidence and stimulate investment growth. Hence, the regulators can improve the mechanisms through which shareholders are able to influence corporate governance, and also support shareholders to embrace a more active role in the governance of their portfolio companies.

The limitations of the current study are represented by the small number of observations and the short research time period. As a future direction for further research, we seek to extend the study sample, as well as to design investment strategies similar to Gompers et al. (2003).

\section{References}

Aggarwal, R., Erel, I., Stulz, R., \& Williamson, R. (2009). Differences in governance practice between U.S. and foreign firms: Measurement, causes, and consequences. Review of Financial Studies, 22(8), 3131-3169. http://dx.doi.org/10.1093/rfs/hhn107

Bauer, R., Frijns, B., Otten, R., \& Tourani-Rad, A. (2008). The impact of corporate governance on corporate performance: Evidence from Japan. Pacific-Basin Finance Journal, 16(3), 236-251. http://dx.doi.org/10.1016/j.pacfin.2007.05.001

Bauer, R., Guenster, N., \& Otten, R. (2004). Empirical evidence on corporate governance in Europe: The effect on stock returns, firm value and performance. Journal of Asset Management, 5(2), 91-104. http://dx.doi.org/10.1057/palgrave.jam.2240131

Bauwhede, H. W. (2009). On the relation between corporate governance compliance and operating performance. Accounting and Business Research, 39(5), 497-513. http://dx.doi.org/10.1080/00014788.2009.9663380

Bebchuk, L. A., \& Hamadani, A. (2009). The elusive quest for global governance standards. University of Pennsylvania Law Review, 157(5), 1263-1317.

Bebchuk, L. A., Cohen, A., \& Ferrell, A. (2009). What matters in corporate governance? The Review of Financial Studies, 22(2), 783-827. http://dx.doi.org/10.1093/rfs/hhn099

Beiner, S., Drobetz, W., Schmid, M. M., \& Zimmermann, H. (2006). An integrated framework of corporate governance and firm valuation. European Financial Management, 12(2), 249-283. http://dx.doi.org/10.1111/j.1354-7798.2006.00318.x

Bhagat, S., \& Bolton, B. (2008). Corporate governance and firm performance. Journal of Corporate Finance, 14(3), 257-273. http://dx.doi.org/10.1016/j.jcorpfin.2008.03.006

Black, B. S., Jang, H., \& Kim, W. (2006a). Does corporate governance predict firms' market values? Evidence from Korea. The Journal of Law, Economics, \& Organization, 22(2), 366-413. http://dx.doi.org/10.1093/jleo/ewj018

Black, B. S., Love, I., \& Rachinsky, A. (2006b). Corporate Governance indices and firms' market value: Time series evidence from Russia. Emerging Markets Review, 7(4), 361-379. http://dx.doi.org/10.1016/j.ememar.2006.09.004

Bozec, Y., Bozec, R., \& Dia, M. (2010). Overall governance, firm value and deviation from one share: One vote principle. International Journal of Managerial Finance, 6(4), 305-328. http://dx.doi.org/10.1108/17439131011074468

Brown, L. D., \& Caylor, M. L. (2006). Corporate governance and firm valuation. Journal of Accounting and Public Policy, 25(4), 409-434. http://dx.doi.org/10.1016/j.jaccpubpol.2006.05.005

Brown, L. D., \& Caylor, M. L. (2009). Corporate governance and firm operating performance. Review of Quantitative Finance and Accounting, 32(2), 129-144. http://dx.doi.org/10.1007/s11156-007-0082-3

Bruno, V., \& Claessens, S. (2010). Corporate governance and regulation: Can there be too much of a good thing? Journal of Financial Intermediation, 19(4), 461-482. http://dx.doi.org/10.1016/j.jfi.2009.10.001

Cheung, Y. L., Connelly, J. T., Limpaphayom, P., \& Zhou, L. (2007). Do investors really value corporate governance? Evidence from the Hong Kong market. Journal of International Financial Management \& Accounting, 18(2), 86-122. http://dx.doi.org/10.1111/j.1467-646X.2007.01009.x

Chhaochharia, V., \& Laeven, L. (2009). Corporate governance norms and practices. Journal of Financial 
Intermediation, 18(3), 405-431. http://dx.doi.org/10.1016/j.jfi.2008.10.001

Core, J. E., Guay, W., \& Rusticus, T. (2006). Does weak governance cause weak stock returns? An examination of firm operating performance and investors' expectations. The Journal of Finance, 61(2), 655-687. http://dx.doi.org/10.1111/j.1540-6261.2006.00851.x

Core, J. E., Holthausen, R. W., \& Larcker, D. F. (1999). Corporate governance, chief executive officer, and firm $\begin{array}{llll}\text { performance. Journal of Financial } & \text { Economics, }\end{array}$ http://dx.doi.org/10.1016/S0304-405X(98)00058-0

Cremers, K. J. M., \& Nair, V. B. (2005). Governance mechanisms and equity prices. The Journal of Finance, 60(6), 2859-2894. http://dx.doi.org/10.1111/j.1540-6261.2005.00819.x

Daines, R. M., Gow, I. D., \& Larcker, D. F. (2010). Rating the ratings: How good are commercial governance ratings? Journal of Financial Economics, 98(3), 439-461. http://dx.doi.org/10.1016/j.jfineco.2010.06.005

Demsetz, H., \& Lehn, K. (1985). The structure of corporate ownership: causes and consequences. Journal of Political Economy, 93(6), 1155-1177.

Doidge, C., Karolyi, G. A., \& Stulz, R. M. (2007). Why do countries matter so much for corporate governance? Journal of Financial Economics, 86(1), 1-39. http://dx.doi.org/10.1016/j.jfineco.2006.09.002

Drobetz, W. (2002). Corporate Governance-Legal fiction or economic reality. Financial Markets and Portfolio Management, 16(4), 431-439. http://dx.doi.org/10.1007/s11408-002-0401-6

Drobetz, W., Schillhofer, A., \& Zimmermann, H. (2004). Corporate governance and expected stock returns: Evidence from Germany. European Financial Management, 10(2), 267-293. http://dx.doi.org/10.1111/j.1354-7798.2004.00250.x

Durnev, A., \& Kim, E. H. (2005). To steal or not to steal: Firm attributes, legal environment, and valuation. The Journal of Finance, 60(3), 1461-1493. http://dx.doi.org/10.1111/j.1540-6261.2005.00767.x

Eisenberg, T., Sundgren, S., \& Wells, M. T. (1998). Larger board size and decreasing firm value in small firms. Journal of Financial Economics, 48(1), 35-54. http://dx.doi.org/10.1016/S0304-405X(98)00003-8

El Mehdi, I. K. (2007). Empirical evidence on corporate governance and corporate performance in Tunesia. Corporate Governance: An International Review, 15(6), 1429-1441. http://dx.doi.org/10.1111/j.1467-8683.2007.00655.x

Epps, R. W., \& Cereola, S. J. (2008). Do institutional shareholder services (ISS) corporate governance ratings reflect a company's operating performance? Critical Perspectives on Accounting, 19(8), 1135-1148. http://dx.doi.org/10.1016/j.cpa.2007.06.007

Ertugrul, M., \& Hegde, S. (2009). Corporate governance ratings and firm performance. Financial Management, 38(1), 139-160. http://dx.doi.org/10.1111/j.1755-053X.2009.01031.x

Fama, E. F. (1980). Agency problems and the theory of the firm. The Journal of Political Economy, 88(2), 288307.

Garay, U., \& González, M. (2008). Corporate governance and firm value: The case of Venezuela. Corporate Governance: An International Review, 16(3), 194-209. http://dx.doi.org/0.1111/j.1467-8683.2008.00680.x

Gompers, P. A., Ishii, J. L., \& Metrick, A. (2003). Corporate governance and equity prices. The Quarterly Journal of Economics, 118(1), 107-155. http://dx.doi.org/10.1162/00335530360535162

Gujarati, D. N. (2003). Basic econometrics (4th ed.). New York: McGraw-Hill.

Hart, O., \& Moore, J. (1995). Debt and seniority-an analysis of the role of hard claims in constraining management. The American Economic Review, 85(3), 567-585.

Hodgson, A., Lhaopadchan, S., \& Buakes, S. (2011). How informative is the Thai corporate governance index? A financial approach. International Journal of Accounting and Information Management, 19(1), 53-79. http://dx.doi.org/10.1108/18347641111105935

Jensen, M. C. (1986). Agency costs of free cash flows, corporate finance, and takeovers. The American Economic Review, 76(2), 323-329.

Jensen, M. C. (1993). The modern industrial revolution, exit, and the failure of internal control systems. The Journal of Finance, 48(3), 831-880. http://dx.doi.org/10.1111/j.1540-6261.1993.tb04022.x

Jensen, M. C., \& Meckling, W. H. (1976). Theory of the firm: Managerial behavior, agency costs, and ownership 
$\begin{array}{lllll}\text { structure. } & \text { Journal } & \text { Financial } & \text { Economics, } & 3(4),\end{array}$ http://dx.doi.org/10.1016/0304-405X(76)90026-X

Johnson, S. A., Moorman, T. C., \& Sorescu, S. (2009). A reexamination of corporate governance and equity prices. Review of Financial Studies, 22(11), 4753-4786. http://dx.doi.org/10.1093/rfs/hhp018

Kaplan, S., \& Zingales, L. (1997). Do investment-cash flow sensitivities provide useful measures of financing

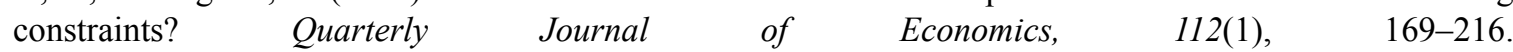
http://dx.doi.org/10.1162/003355397555163

Klapper, L. F., \& Love, I. (2004). Corporate governance, investor protection and performance in emerging markets. Journal of Corporate Finance, 10(5), 703-728. http://dx.doi.org/10.1016/S0929-1199(03)00046-4

Larcker, D. F., Richardson, S. A., \& Tuna, I. (2007). Corporate governance, accounting outcomes, and organizational performance. The Accounting Review, 82(4), 963-1008.

Lehn, K., Patro, S., \& Zhao, M. (2007). Governance indexes and valuation: Which causes which? Journal of Corporate Finance, 13(5), 907-928. http://dx.doi.org/10.1016/j.jcorpfin.2007.07.002

Licht, A. (2003). Cross-listing and corporate governance: Bonding or avoiding? Chicago Journal of International Law, 4(1), 141-163.

Myers, S. C. (1977). Determinants of corporate borrowing. Journal of Financial Economics, 5(2), 147-175. http://dx.doi.org/10.1016/0304-405X(77)90015-0

Renders, A., Gaeremynck, A., \& Sercu, P. (2010). Corporate-governance ratings and company performance: A cross-European study. Corporate Governance: An International Review, 18(2), 87-106. http://dx.doi.org/10.1111/j.1467-8683.2010.00791.x

Stulz, R. M. (1990). Managerial discretion and optimal financing policies. Journal of Financial Economics, 26(1), 3-27. http://dx.doi.org/10.1016/0304-405X(90)90011-N

Vintilă, G., \& Gherghina, Ş. C. (2012). An empirical examination of the relationship between corporate governance ratings and listed companies' performance. International Journal of Business and Management, 7(22), 46-61. http://dx.doi.org/10.5539/ijbm.v7n22p46

Zweibel, J. (1996). Dynamic capital structure under managerial entrenchment. The American Economic Review, 86(5), 1197-1215.

\section{Copyrights}

Copyright for this article is retained by the author(s), with first publication rights granted to the journal.

This is an open-access article distributed under the terms and conditions of the Creative Commons Attribution license (http://creativecommons.org/licenses/by/3.0/). 